\title{
Grzeczność (staropolska) Gombrowicza
}

Marcin Cieński 


\section{Marcin Cieński}

\section{Grzeczność (staropolska) Gombrowicza}

Rozważania o grzeczności (staropolskiej) (iombrowicza rozpocznę od znanego cytatu z Dzicmnika, stanowiącego fragment wywodu o historii rodı pisarza:

Babka moja, Onufrowa Gombrowiczowa, była 1)ąbrowska (z lepszych), urodzona z Benislawskiej (dobrze), która rodziła się z baronówny Toplickiej (dobrze), która rodziła się z Sołtanówny, córki marszałka nadwornego Soltana i Radziwiłłówny (doskonale)'.

Na pierwszy plan wysuwa siç tu z pewnością żywioł prowokacji, lecz dobrze dostrzegalne są i inne, pomniejsze. Na pewno znajduje się wśród nich ironia spleciona z autoironią, bez trudu dostrzec można snobizm oraz staropolskie zamiłowanie do szperania w genealogii wlasnej i cudzej, której niemalze symbolicznym wykładnikiem byly herbarze Niesieckiego czy Paprockiego². Do tych mniej ekspansywnych, choć eksponowanych w przytoczonym urywku aspektów, należy też grzeczność, której znaczenie - jeśli dobrze przyjrzeć się ku1turowym i „tradycjonalistycznym” fundamentom wywodu o genealogii babki diarysty - okazuje się bardzo istotne.

Powiedzieć by wręcz można, że ów dominujący - w przytoczonym urywku - żywioł prowokacji znaczenie swoje buduje w opozycji do grzeczności, i dopiero wówczas, gdy weźmiemy pod uwagę te oba elementy, odsłania się zasadnicza „jakośc” wypowiedzi autora (podmiotu) Dziennika. W tym niewielkim, jednozdaniowym fragmencie koncentruje się - niczym w soczewce - jedna z zasadniczych kulturowych, literackich i osobowościowych opo-

\footnotetext{
' W. Gombrowicz, Dzicta, red. naukowa tekstuJ. Bloński. t. 9: Dziemmik. 1961-1966. Kraków 1986, s. 214. Zob. uwagi Konstantego Jelcńskiego o wsponnicniach Janiny z Puttkamerów Źóltowskicj Imme zasy, inmi hadzic zatytulowane Sidskie, aniclskie?. [w:] K. Jeleński, Zlicgi okolic=nośii. Paryż 1982, s. 138-139.

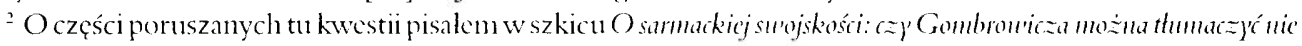

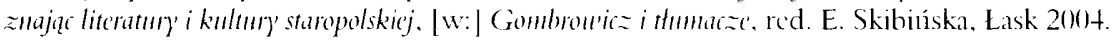


zycji obecnych w twórczości Witolda Gombrowicza. Tego rodzaju soczewek czy pryzmatów wskazać dałoby się bardzo dużo, bez trudności udałoby się również zebrać obszerny materiał tekstowy dotyczący funkcjonowania (szeroko rozumianych) zachowań grzecznościowych ukazywanych w dzielach autora Kosmosu. Na jego podstawie - a byłoby to juz zadanie nierównie bardziej złożone - można by dążyć do zrekonstruowania "gramatyk grzeczności" opisujących zachowania bohaterów poszczególnych utworów, odsłaniających ważny składnik systemów interakcji, fundamentalnych — jak pokazał to Zdzisław Lapiński ${ }^{3}$ — w świecie Gombrowiczowskiej literatury.

Inną jednak - rozleglejszą - kwestią staje się grzeczność (ujmowana właśnie w swoistym sprzężeniu z prowokacją), gdy spojrzeć na będącą "własnością" autora Bakakaju wizję świata i panujących w nim relacji oraz gdy rozważać funkcjonowanie ,ja-Gombrowicza”, czyli Gombrowicza-podmiotu, ksztaltującego swoją tożsamość (a jednocześnie budującego tożsamościową narrację czy autonarrację) $)^{+}$nie tylko w świecie „literackości”, ale też w świecie rzeczywistym, „przenikającym” się w specyficzny sposób z literaturą. Więc inne okazałyby się zapewne od Gombrowicza literackich ,gramatyk grzeczności” jego „gramatyki” filozoficzne czy światopoglądowe (związane z Formą), a jeszcze inny charakter mialaby zapewne „grzeczność osobista" (choć też prowokacją - jak świetnie wiadomo - podszyta) Gombrowicza zaświadczona we wspomnieniach, w korespondencji, w całej dokumentacji „walki o sławę”.

Przywołałem całą tę rozległą perspektywę, by podkreślić wycinkowość mojego spojrzeni: i jednocześnie jego nieuniknioną szkicowość. Zależało mi jednak na otwarciu szerszej perspektywy, bowienn nie chciałbym mówić o „wpływie” staropolskiej grzeczności na teksty i obraz świata autora Truns-Atlantyłku, lecz ukazać jeden z komponentów calościowego, stworzonego przez niego systemu. Komponent, który funkcjonuje w szerszym - a bardzo znaczącym - kontekście procesu transformowania przez Gombrowicza tradycji kulturowej i li. terackiej, spierania siç z nią, jej transgresji, „przywłaszczania” (czy może: „przewłaszczania”. dla własnych celów, tworzenia — wedle formuły Michała Głowińskiego — „nadliteratury”

\footnotetext{
3 Zob. Z. Lapiński. Ja Ferdydurke. Gombrouvica suriat interakeji, Lublin 1985, zwd. Akije i interakeje. s. 25-42.

${ }^{+}$W kwestii relacji między narracją a tożsamością zob. m. in. K. Rosner. Narraja, to ̇̇amośc iczas, Kraków 2003 1. Ricocur, O solic samy'm jako imm?'m, th. B. Chetstowski. Warszawa 2003; A. Burzyńska, Karicra narracji. O zmro

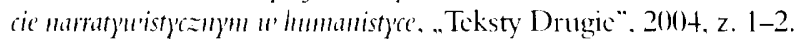

"Przytaczan tu fragment rozważań Głowinískiego, który precyzyjnic wyjaśnia w twórczości Gombrowicz dzialanie pewnych mechanizmów, stanowiących istotny kontekst dla prowadzonych dalej obserwacji doty czących grzeczności. ,Jego [Gombrowicza] dzicło, tak przeszłością nasycone i tak od przeszłości zależne, ni jest jednak dziclem tradycjonalisty'cznym. (...) Tradycja nie jest tu bowicm dyktatem, nic jest tez wzorem d takicgo naśladowania. którc zakladałoby wicrność i sklaniało do pow tórzcń tego, co zdziałali artyści minioneg izasu. Jest przede wszystkim swoistym problemem, jaki przed pisarzem stoi. Stanowi punkt wyjścia, sweg rodzaju odskoczniç, ale też tworzy wyzwanic. staje się kwestia, jaką musi rozwiązać, gdy zmierza do stworze nia czegoś. co chớ w przeszlości zanurzone. jest nowe i nic daje się sprowadzić do repetycji tego, co znane ju i widziane. Przede wszystkim jednak stanowi buduke. Budulec nie slużący powtarzaniu tego, co już z nieg zostalo skonstruowanc. budulec, którego powstają struktury nowe, dotychezas nieznane, przez tradycję ni podpowiadane, bow poprzednich epokach historycznych po prostu nicmożliwe. Gombrowicz, zawsze oryg nahyy, nowatorski, często zaskakujący: buduje literaturę z literatury. Jego domeną — od mlodzicńczych opc
} 
W tej perspektywie łatwiej czytelna, mam nadzieję, staje się akcentowana już wyżcj — nierozerwalna właściwie u Gombrowicza - łączność grzeczności i prowokacji. Prowokacji również — powiedzieć by można - findamentalnej, polegającej na ukazywaniu rytualizacji, która prowadzi do „pustości”, wyczerpania, pewnych zachowań, konwencji, skostniałych w tradycji obyczajowej czy językowej określonych gestów, obudowanych znaczeniani, czasem nawet wyniesionych na postument "niezbywalnych skladników” narodowego czy państwowego charakteru, polskości.

Taki wlaśnie składnik narodowej tożsamości stanowi bardzo szeroko rozumiana „tradycja szlachecka”, a właściwie pewne elementy kultury szlacheckiej Pierwszej Rzeczpospolitej, które zostaly - mówiąc w uproszczeniu — „wyselekcjonowane” i swoiście zinterpretowane po utracie niepodległości, w pierwszych dziesięcioleciach XIX wiekı, i weszły w skład narodowego dyskursu tożsamościowego, funkcjonującego do końca tego stulecia i w początkach następnego. Fundamentalny przewrót w mechanizmach interpretowania czy nawet kreowania tej tradycji przyniosło odzyskanie niepodleglości: Druga Rzeczpospolita tworzy nowy model nadawania znaczeń Rzeczpospolitej Pierwszej, wpisuje tradycję szlachecką w inne już porządki kulturowe, dla których pozbawienie Polaków wlasnego państwa nie stanowi podstawowego (wyjściowego) punktu'. Pozwala to zatem (przynajmniej w teorii) na dokonanie reinterpretacji „narodowo-patriotycznego dyskursu” wiedzionego „ku pokrzepieniu serc”, a wykorzystującego tradycję szlachecką czy sarmacką. Dla Gombrowicza w Dwudziestoleciu było na takie (prowokacyjne) przedsięwzięcie jeszcze zbyt wcześnie (choć pierwsze sygnały polemiki z tą tradycją pojawily się już w $\left.F(r d)^{\prime} d u r k e^{\prime}\right)^{7}$, właściwy moment nadszedl dopicro dzięki doświadczeniom emigracyjnym i podczas nich: przeprowadza je w Ślubie, Trans-Atlantyku, Pornografii, oczywiście — choć w rozmaity sposób — w Dziemniku i w innych wypowiedziach (oficjalıych i prywatnych).

Nie można jednak zapominać, że kwestie wskazane wyżej składały się na jeden tylko aspekt calego zjawiska funkcjonowania „szlacheckości” jako tradycji. Drugi tworzyła realua obecność w życiu narodowym - i później państwowym - żywych jej depozytariuszy, faktycznych (i prawnych) spadkobierców stanu szlacheckiego, nznających siebie za dzicdziców szlacheckiej mentalności, kultury i obyczaju. Oczywiście warstwa „ziemiańska” byla w gruncie rzeczy wyraźnie odmienna od szlachty — i sarmackiej, i tej oświeconej - lecz pozostaly pewne mechanizmy kulturowe (często jako zrytualizowane gesty) i świadomość kontynuacji

wiadań po Kómos i Operetkę - jest swojego rodzaju na d l i tera t u ra" (M. Gkowiński, Gombrourizi inadliteratura. Kraków 2()02, s. 7: podkr. autora).

"To wyraźnic intuicyjne stwierdzenic wymagaloby, rzecz jasna. szerszych rozważan. ale wystarczy tylko zatıważyć, ile „historii obyczajów w dawncj Polsce” wíwczas powstalo, czy przywolać znaczną czçść badań literaturoznawczych nad dawnymi epokami; jako zmamicnny przyklad mogłaby tu posluzyé synteza Ignacego Chrzanowskicgo (1906, podręcznik akademicki od 1930) oraz podejonowance w stosunku do nicj próby zmniany sposobu widzenia przeszlości, dotyczące zwlaszcza sfery aksjologicznej.

7 Tu jednak ważnicjsze okazuje siç ośmieszenic wyznawezego i manipulatorskiego stostmku do romantycznych wieszczów oraz kompromitacja szkolncj polonistyki ..od pana Zagłoby”. 
tradycji jako wartość fundamentalna, choć nadwątlana pod wpływem przeobrażeń (gospodarczych, politycznych i kulturowych) zachodzących w Drugiej Rzeczpospolitej ${ }^{\natural}$.

Z tego wlaśnie „ziemiańskiego" kręgu wywodził się i w nim funkcjonował Witold Gombrowicz: „dziedzic z Sandomierskiego”, jak określil go w precyzyjnym szkicu biograficznym Jerzy Jarzębski", a w młodości wytrwały badacz rodzinnej przeszłości. Studiował on przecież, a przynajmmiej miał w ręku, gromadzone przez wieki dokumenty odsłaniające prawdziwe -a nie zmistyfikowane - oblicze szlacheckiego życia, kultury ${ }^{11}$; choć oczywiście trudno powiedzieć, co był w stanie jako kilkmuastolatek wyczytać z tych materiałów, niełatwych do interpretacji nawet dla historyków - ważne jest, że rodzinne czy rodowe archiwum stało się istotnym źródtem jego myślenia o szlachcie i kulturze Pierwszej Rzeczpospolitej. Oczywiście, poza wskazanymi tu kwestiami strategicznymi (widzenie / ujmowanie grzeczności w powiązaniu z prowokacją), kulturowymi (odnoszącymi się do szlacheckości/ziemiaństwa, ich ewolucji oraz zmian nastawienia do nich pisarza) i osobistymi (wynikającymi z realnej biografii autora), na sposób ksztaltowania przez Gombrowicza mechanizmów grzeczności w świecie przedstawionym jego utworów istotny wpływ miały też konwencje literackie, gatunkowe, określające na przykład sposoby kreowania postaci, ich typologię, możliwe czy dopuszczalne w określonej sytuacji zachowania itd. Każdorazowo elementy grzecznościowe należałoby więc ujmować i rozpatrywać nie jako istniejące w postaci abstrakcyjnej, lecz w ich uwiklaniı w pewien mechanizm literacki, w ramach konwencji, powiedzmy, powieściowych czy dramaturgicznych.

W dalszym ciągu szkicu odwoływać się będę wlaśnie do powieści Gombrowicza — Ferdydurke, Trans-Atlant)ku i Pornografii - obserwując w nich funkcjonowanie grzecznościowych rytuałów, w których rozpoznać można staropolskie (szlachecko-sarmackie) korzenie, źród$\mathrm{la}^{11}$. Interesujące wydają mi się takie przypadki, w których tego typu zachowania w obrębie świata przedstawionego odsylają̧ do kwestii fundamentalnych dla światopoglądu Gombrowicza: i jako autora powieści, i jako ,badacza” polskości, zanurzonego w niej i podejmującego nad nią refleksję - refleksję trudną, niegrzeczną, prowokacyjną.

Zacznijmy od Ferdydurke. Uciekający Józio i Miętus trafiają do Bolimowa, posiadlości wujostwa narratora. Zetknięcie z dworkiem zaczyna się od prezentacji, zaś potem:

Ściskanie rąk, całowanie policzków, zahaczanie częściami ciała, objawy radości i gościnności, prowadzą nas do salonu, sadzają na starych biedermeierach i za-

\footnotetext{
${ }^{x}$ Chçtnic powiedzialbym - nicco zartobliwic - że utwory Gombrowicza odbiegają od pewnych dawnych (także dziewiçtnastowiecznych) gatunków i tckstów: szlacheckiego pamiçtnika i diariusza, sielanki, gawędy szlacheckicj prozą i wicrszem. Panta Tadeusza, a także powicści historyczncj, od Jana z Técz)'ma przez Kraszewskicgo po Tryłogį̣. w sposób analogiczny do tego. w jaki zicmiaństwo odchodzi od wzorca szlacheckicgo w życiu i kodeksic zachowań.

"To określcnie uważam za nicporównanic trafnicjsze od formuly .jaśnicpanicz”. którcj użyła Joanna Siedlecka.

1) Zob. mp. A. Stawiarska, Gombrouric u' preedirojennej Polsce, Kraków 20)(1, s. 9-17.

' Analizowane powieści Witolda Gombrowicza cytuję za Dziełami pod red. Jana Blońskiego (zob. przyp. 1) podając w nawiasic po cytacic skrót tytulu i numer strony: t. 2, Ferd)'durke (F); t. 3, Truns-Atlant)'k (TA); t. IV Pornografia (P).
} 
pytują o zdrowie, jak się miewamy — z kolei ja zapytuję o zdrowie i rozmowa o chorobach wywiązuje się, lapie i nie popuszcza już (F 198),

przechodząc - dopowiedzmy - w martwą wyliczankę inkrustowaną rozważaniami o lekarzach. W tym fragmencie rytual gościnności - jeden z podstawowych składników grzeczności staropolskiej — zostaje w samym swoim stawaniu się zdemaskowany i ukazany w perspektywie ironiczno-groteskowej jako zespól gestów i słów pustych. A zauważyć by należało, że przecież jest to również topiczna w polskiej literaturze od-romantycznej scena powrotu bohatera do dworu, który opuścił dzieckiem, wraca zaś młodzieńcem, po szkołach. Pamięć o przeszłości zostaje w zachowaniach w Bolimowskim dworku unieważniona, nikt nie spodziewa się, by w typowych — grzecznych - zachowaniach doszukiwać się drugiego dna, związku z „życiem szlacheckich przodków”. Grzeczność okazuje się więc tu mechaniczna, relacje interpersonalne i nastawienie podmiotowe zastępuje powtarzalnością gestów ..czlowieka-[grzecznej] maszyny", wykorzeniona z oparcia w tradycji przeksztalca się w rytual.

Rytuał - dodać należy — coraz mocniejszy, poddający osoby zachowujące się według niego swej dominacji, zgodnie z „klasycznymi” założeniami Gombrowicza teorii Formy. Rytual ten rozpaść się może dopiero pod wplywem prowokacji, i to takiej, która uderzy w fundamenty dworkowego szlacheckiego bytowania. Można się oczywiście spierać, czy do szlacheckiej grzeczności czy tylko do tolerowanego - choć uświęconego tradycją - obszaru prerogatyw szlachty należalo bicie parobków po pysku. Natomiast z pewnością odwrócenie sytuacji - bicie po gębie kogoś z „państwa” przez parobka — bylo nie do pomyślenia, nie tylko w kategoriach grzeczności, ale w kategoriach fundamentalnego porządku narzucanego przez istnienie systemu stanowego. A taką wlaśnie sytuację — naruszenia podstawy ziemiańskiego bytowania wskutek naruszenia cielesności (dokladnie: gęby) kogoś z „państwa” — zaaranżowal Miętus.

Znamienne są refleksje Józia, w których wyraźnie daje się słyszeć glos autorski:

Pojąlem owej strasznej nocy (...) tajemnicę dworu wiejskiego, ziemiaństwa i obywatelstwa, tajemnicę, której wielorakie i mętne symptomy od pierwszej chwili napawały mnie przeczuciem trwogi pogębnej i gęby! Slużba byla tą tajemnica. Chamstwo było tajemnicą państwa. (...) Czemu [wuj] nas emablowal z tak usilną kinderstubą, skąd tyle grzeczności i względów, tyle manier i dobrego tonu? Aby się odróżnić od shużby i przeciw slıżbie zachować pański obyczaj (F 214).

Gombrowicz w tym momencie uniwersalizuje pewną relację, którą — w specyficznej postaci — obserwuje i ukazuje w realiach Międzywojnia. Uznaje, jakoby „było tak zawsze”, choć trudno przypuścić, żeby rzeczywiście w przemyślany, „socjologiczny” sposób zrównywał sarmacką obyczajowość z dworkowymi zwyczajami. Wydaje się jednak, że nie o niewiedzę tu chodzi, lecz o bunt, którego znamieniem jest prowokacja. Jest to bunt nie przeciw „grzeczności”, a przeciwko jej (cynicznemu) wykorzystaniu, przeciwko uczynieniu z niej 
maski w relacjach międzyosobowych, które w tym ujęciu pokazane zostają - zgodnie z tradycyjną zasadą reprezentatywności i typowości powieści realistycznej - jako charakterystyczne dla pewnej szerszej grupy czy stanu.

Zatem bohaterowie Gombrowicza w Ferdydurke nie moga być „nie-grzeczni”, lecz muszą buntować się - wlaśnie przeciw ciążącej im (choć chwilami również uwodzicielskiej i pociągającej) tradycji grzeczności staropolskiej, dziś znanej im w ziemiańsko-dworkowej postaci. Więc buntując się przeciw temu, co sądzą, że jest tradycją, w gruncie rzeczy sprzeciwiają się jej postaci zmistyfikowanej, przeksztalconej w kulturowo-społeczny pozór i maskę. „Ziemianska” odmiana grzeczności (o staropolskich korzeniach) dopełnia w pierwszej powieści Gombrowicza wizerunki grzeczności ..szkolnej” i „rodzinnej” (w wersji nowoczesnej), stanowi składową społecznej "gęby”, ale jednocześnie — zwłaszcza gdy czytać Ferdydurke w kontekście późniejszej twórczości jej autora - odsłania wyraźny komponent uniwersalny, abstrakcyjny, wysublimowany, wiążący się z naturą (schematyczną) ludzkich relacji.

Odmienne mechanizmy pisarskiego i światopoglądowego „zastosowania” grzeczności występują w Trans-Atlantyku, choć sprzężenie jej z prowokacją ma znaczenie i w tej powieści. Zasadniczym czynnikiem modyfikującym jej funkcjonowanie stało się odwołanie się przez Gombrowicza - dla usytuowania w centrum rozważań kwestii narodowego charakteru Polaków - do językowego, stylistycznego oraz kulturowego wykladnika (i jednocześnie źródla) sarmatyzmu i szlacheckiej, a właściwie ziemiańsko-dworkowej, polskości, zaistniałej w życiu zbiorowym między innymi dzięki ".Sienkiewiczowskiemu” modelowi lektury tradycji Pierwszej Rzeczpospolitej.

Wybór barokowo-sarmackiego „.podłoża” czy „podglebia” tekstowego — jako jednegc z podstawowych, bo przecież fundamentem Trans-Atlanty'ku jest również Pan Tadeusz - uzasadnia odsłanianie ciagłości pewnych zachowań, postaw czy rytuałów, powiedzieć by można że pokazuje ich „długie trwanie” i jednocześnie „wyplynięcie” z nich znaczeń, które byly kulturowo motywowane i uzasadnione czasowo. Procedury prowadzące do ich ponowienia okazują siç w zmienionej (geograficznie, kulturowo, czasowo) rzeczywistości bezproduktywne puste, a jednocześnie przyzwyczajenie do ich powtarzania okazuje się — wśród Polaków — zadziwiająco mocne. Tu dwa przykłady. Pierwszy ukazuje przyjęcie powieściowego „Gom. browicza" przez dyplomatę Rzeczpospolitej, posła Kosiubidzkiego:

Zachowaniem i ukladem swoim niezwykły wzgląd na wysoką godność swoją wykazywał i każdem swem poruszenicm honor sobie świadczyl, a tyż i tego z kim mówil sobą silnie bez przerwy zaszczycal, a że juz to prawie na kolanach z nim się rozmawiało. Zaraz więc, placzem wybuchnąwszy, jemu do nóg padtem i dloń calowatem; a stuzby swoje, krew, mienie ofiarowując, o to upraszalem, aby mnie w takiej chwili św., wedle woli św., rozumienia swego użył i moja rozporządzal osobą. Najlaskawiej mnie a siebie słuchaniem św. swojem zaszczycając, poblogosławil i okiem łypnął, a potem mówi: - Już tobie więcej jak 50 pezów (sakiewkę wyjąl) dać nie mogę (TA 18). 
Przed oczami czytehnika odtworzona zostaje scena rozmowy magnata z drobnym szlachcicem, związanego z możnym „.panem bratem” relacją klientalnej zależności ${ }^{12}$. Odpowiednie do tej sytuacji są więc reguły grzeczności, z padnięciem petenta do nóg opiekuna na czele. Stylizacja ma przy tym charakter palimpsestowy, bo rzeczywistość obyczajowa i historyczna jest tu przefilltrowana przez zapis źródlowy (z epoki), przez wizerunek epoki ksztaltowany w XIX wieku, przez stereotypy i wreszcie przez groteskowość Gombrowiczowskiego ujęcia. Zasadniczy efekt dotyczy „nadmiarowości” owej grzeczności, nieadekwatności grzecznościowego szablonu do sytuacji, a poczucie to pisarz wzmacnia jeszcze, stosując wielokrotnie powtórzenie formul i gestów.

Drugi z zapowiedzianych przykładów dotyczy polowania, które posel ma urządzić, aby dać gościon cudzoziemskim możliwość pojawienia się na miejscu pojedynku Tomasza z Gonzalem i wysłuchania oracji o .. I Ionorze, Czci, Odwadze naszej” (TA 68). Plan ten powstaje podczas obrad w poselstwie, przy czym wyłania się on z ciạgu „złych pomysłów”, które jednak zostają zaprotokolowane, nabierając w ten sposób obowiązującej i obezwladniającej mocy. Okazıje się jednak, że zorganizowanie polowania będzie trudne, gdyż, choć uda się zgromadzić wszystkie akcesoria, to nie sposób zapewnić przedmiotu polowania z chartami, czyli szaraków. Polowanie należalo do typowych rytuałów szlacheckich i obrosło całym skomplikowanym systemem reguł grzeczności, więc jego przywołanie przez Gombrowicza ma tu niewątpliwą ważność symboliczıą (abstrahıją̧ już od wartości intertekstualnej tego wątku: zwłaszcza wobec Pana Tadeusza). Bezsensowne urządzanie polowania z chartami na upatrzonego w warunkach argentyniskich odsłania typowe elementy polskości: chęć pokazania się przed cudzoziemcani, wiarę w rytuały wynikającą z niemuniejętności racjonalnego na nie spojrzenia. Cała grzecznościowa machina polowania staje się więc świadectwem uwikłania w polskość, tego samego, które z całą groteskową mocą odezwie się w historii bractwa ostrogi.

To uwikłanie okazuje się tak silne, że przenoszą je Polacy w najbardziej egzotyczne miejsca, emigracja od niego nie wyzwala; wręcz przeciwnie, rytualy stanowią filtr, przez który emigranci patrzą na cudzoziemską rzeczywistość, zabarwiając ją swojskością ${ }^{13}$. Bo chyba właśnie tak interpretować można odzywanie się w zachowaniach Gonzala w jego olśniewającej luksusem hacjendzie typowych motywów polskiej, szlacheckiej gościnności. Otóż woła on niczym zamaszysty Sarmata:

Hej, shużba, zastawiać, podawać, święto dzisiaj, jazda, gość w dom, Bóg w dom, calym sercem proszę, a uściskajmyż się jeszcze raz, bo to już chyba lepszych Przyjaciól, Braci ja nie miałem, a święto, a święto! (TA 84-85).

I nieco dalej:

'2 Zob. A. Mączak, Klicntela. Nieformalne systemy' u'tadzy' 'u' Polsce i Europie. XI 7-Xt 711 u'. Warszawa 1994, idem,

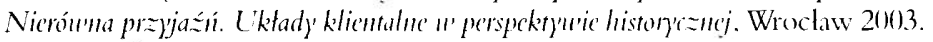

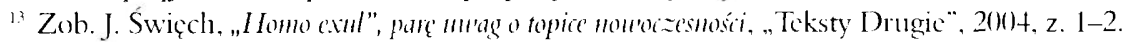


Zawoła: - Nic to, nic to, ani słyszeć nie chcę, jeszcze tego nie było żebym Gości przed nocą wypuszczał! I Iej ha, hej ha, kazałem tyż kola z powozów pozdejmować! (TA 87$)^{1+}$.

Doskonale odgrywa też Gonzalo rolę polskiego szlachcica witającego rzekomo niespodziewany kulig, który odwiedza jego włości.

Znamienne wydaje się przy tym, że w Trans-Atlanty'kn wcale nie pojawia się tak wiele odwołań do staropolskiej grzeczności, jak można by się spodziewać, biorąc pod uwage podłoże stylizacji; trudno je odszukać w całych dość znacznych partiach powieści. Rzecz jednak nie w ilości: są one, po pierwsze, bardzo wyraziste, latwo identyfikowalne, a po drugie, dotyczą często całych skomplikowanych rytuałów - jak polowanie, kulig, wzajemne zachowania, pojedynek. Można więc mówić o dużej intensywności tych odwolań do (staropolskiej) grzeczności, o swoistym kulturowym nasyceniu nimi powieści. Jak się wydaje, służą one właśnie dyskursowi polskości, stanowiąc sygnal nie buntu wobec niej, lecz uwikłania, niemożliwości wyrwania się, wyzwolenia spod jej wpływu, ulegania regułom - wyeksploatowanym — nakazowi bycia spadkobiercą szlacheckiej tradycji zawsze i wszędzie, nawet wśród palm i kolorowych papug, a więc wobec Innego. W efekcie i tu grzeczność staje się dla Gombrowicza formą shuząacą - oczywiście prowokacyjnemu - demaskowaniu, w Trans-Atlant)'ku polegającym na uświadomieniu nam, że jako Polacy w polskość jesteśmy uwikłani, a próby wydostania się z jej rytuałów okazują się niezmiernie (i niezmiennie) bolesne ${ }^{15}$.

Uwagi na temat funkcjonowania grzeczności w Pornografii rozpocząć chcialbyın od dluzszego cytatu, który pozwoli — jak sądzę - we wlaściwej perspektywie zobaczyć sytuację wyjściową powieści. Witolda i Fryderyka, przybywających do dworu Hipolita w Sandomierskiem, wita gospodarz:

Gościnnie i wykwintnie zwrócił się do nas: - Jak dobrze, że panowie przyjechali, ależ proszę cię, Witoldzie, zapoznaj mnie ze swoim przyjacielem... skończyl, zamknął oczy i powtarzal. wargi mu się ruszały. Fryderyk z wielkim

\footnotetext{
it Tujako komentarz fragment z monumentalnego dzicha Bystronia:...Witano chę̧tnie gości, tym niechęctniej z: to wypuszczano milego towarzysza. Ponnysłowość sarmacka wysilala się nad problematem. jak by pożądanege gościa dlużej zatrzymać; nic pomagaly perswazje i prośby, próbowano wstrzymać odjeżdżającego kiclichem tak że czasami gość zanniast do karety, do lóźka wędrowal, o ile go wprost nie odnoszono. Pito strzemiennege na pożegnanie, i tu jeszczc byla możność konceptem lub trunkiem wplynąć na zmianę decyzji. Bardziej rady kahnym środkiem było uniemoźliwienic wyjazdu przez uszkodzenic wozu, najezęścicj przez zdjęcie kól, któn dobrze chowano, by gość nie mógl ich odnaleźć, albo też prościej przez upicie woźnicy. Gość, rad nicrad, mu sial pozostać, klnąc w duszy gospodarza: zwyczaj ten bardzo byl rozpowszechniony i dopicro Krasicki w Pam

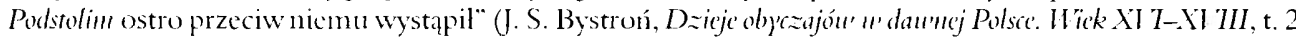
Warszawa 1976, s. 16.3).

15 O modelu polskości i sposobie jej occ ny w pisanym w Trans-Atlant)'k wypowiadali się wiclokrotnic czytelni cy i badacze, sann Gombrowicz równicz zabieral głos w tej kwestii, proponnjąc (a raczcj określając) sposób lek tury swojej powicści i broniąc go wytrwale przed atakami. W tej perspektywie bardzo interesująca - i poucza jąca - okazuje się lektura przckładów tej powicści; w przywoływanymu weześniej tomic Gumbrowicz i thumacz pisząo nich M. Tomaszewski („Trans-Atlant\}k" I itoldu Gombrouvicza po francusku) iJ. Jarniewicz (Frazes ifrazco

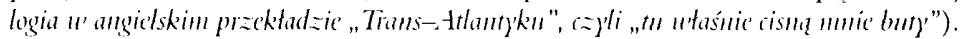


ugrzecznieniem ucałowal rękę pani domu, której melancholia okrasiła się dalekim uśmiechem, której wiotkość delikatnie zatrzepotała... i wciagnną nas wir nawiązywania, wprowadzania w dom, zasiadania, rozmawiania — po owej podróży bez końca - a światlo lampy rozmarzało. Kolacja, do której podawał lokaj. (...) Gdy zaś wyszliśmy po śniadaniu na dziedziniec - dom, biały, piętrowy, z facjatkami w ujęciu świerków i tuj, ścieżek i klombów - który oszołomil nas jak nieskalane zjawisko z dawnego, juz tak odleglego przedwojnia... i w swej dawności nie naruszonej zdawat się być prawdziwszy od teraźnicjszości (...) Ale oto nadchodzi dziedzic, potężny, nabrzmiały, w kurtce zielonej na rozsadzającym cielsku i, zaiste, nadchodzi jak dawniej, pozdrawiając nas z daleka ręką i pyta, jak się nam spało? (P 12-14).

Oczywiście, tak zaczyna się epopeja, może nie .,szlachecka we dwunastu księgach wierszem”, ale „dworkowa”, „ziemiańska”. I latego też na początku ukazany jest lad i harmonia „lepszego świata”, prawie takiego jak sprzed wojny, a z pewnością takiego, w którym istnieje jeszcze nadzieja (a może nawet pewność) przywrócenia ladı, ufność, że znowu będzie jak w Koźmiana Ziemiaństuie polskim czy u Pana Podstolego, lub - patrząc jeszcze dalej w Czarnoleskiej czy Nagłowickicj Arkadii. Dlatego też rytuały grzeczności funkcjonują niezakłóconce, są gwarancją normalności i nadziei, utrzynywaną mimo świadomości niebezpieczeństwa. Jest tu więc podobnie jak w Bolimowie z Ferdydunke: grzeczność i konwenans są gwarancją (jedną z gwarancji) pozycji, ale jednocześnie w dworku I Iipolita już jest inaczej. Nie ujawnia się bunt wewnętrzny, środowiskowy przeciw grzeczności (a jeśli nawet, jest to bunt erotyczny i etyczny, a nie spoleczny). Pojawia siç natomiast świadomość zagrożenia, czegoś, co rozbije ład, unieważniając nie poszczególne reguły grzeczności, lecz ją samą jako całość. Pojawia się świadomość obecności zła, i to obecności wielorakiej, bo zła związanego z wojną i jej zagrożeniami, a jednocześnie zla „zewnę̧trznego, ale uwewnętrznionego”, które wiąże się z osobą Fryderyka.

Na tym właśnie polega jeden z paradoksów Pornografii. Fryderyk. przynajmniej z pozoru przestrzega wszelkich zasad grzeczności, ba, wręcz niejednokrotnie sprawia wrażenie, jakby znajdowal się w pełnej władzy jej konwenansów, a w rzeczywistości sam potrafi ją niejako od środka unieważnić, rozbić, wykorzystać do swoich (obłąkanych) celów. W nim nie można odnaleźć tego rysu, który zmalazł się w portrecie jego - jak się wkrótce okazało — duchowej przeciwniczki, pani Anelii:

...mieliśmy do czynienia nie z zacną wiejską kolatorką w prowincjonalnym wymiarze, ale z osobą, której atmosfera narzucala się przemożną silą. Trudno określić, na czym to polegało. Podobne, jak u Wacława, ale głębsze chyba poszanowanie istoty ludzkiej. Grzeczuość, wynikijąca z wysubtelnionego poczucia wartości (P 61).

Zło, którego nosicielem (jeśli nie nosobieniem) jest Fryderyk, potrafi przetamać opór i tej duchowej wielkości, potrafi zaszczepić niepokój, podważyć owe mocne wartości. Grzecz- 
ność okazuje się, tym razem, nie powtarzalnym rytualem, który okrywa pustkę, ale w gruncie rzeczy nabiera wymiaru etycznego. Jednocześnie, a wlaściwie nawet: mimo to, pozostaje jednak domeną gry, inscenizacji, reżyserii, której mistrzem i wyznawcą jest Fryderyk. Dlatego pozorność jego grzecznoścjowej inscenizacji, odbywającej się jakby poza dobrem i zlem, udziela się w krytycznym momencie pani Amelii, czyniąc z niej kogoś innego, wytrącając ją z jej dotychczasowych sposobów reagowania: kara za moment odstępstwa czy raczej zawahania okazuje się okrutna i natychmiastowa.

Podobnie rozpada się poczucie wartości w bohaterach rozważających kwestię wykonania wyroku na Siemianie. Dwa cytaty, pierwszy z rozmowy Witolda z właścicielem majątku:

Gdy jednak zapytałem, co zamierzają robić, spotkała mnie odpowiedź prawie ordynarna. - Co pan chce? Niè ma o czym gadać! Musi być zrobione! Ton Hipolita wyjawial piorunującą zmianę w naszych stosunkach. Przestałem być gościem, byłem na słuzbie, wsadzony wraz z nimi w ostrość, w okrucieństwo, które zwracało się tyleż przeciw nam co przeciw Siemianowi (P 104).

Drugi urywek pochodzi z dyskusji, w której Fryderyk dąży do powierzenia zadania Karolowi:

„Zwyczajne” zlikwidowanie Siemiana juz nie wchodziło w rachubę po naszych trzech odmowach pelnych abominacji. To stalo się wstrętne pod naciskiem naszego obrzydzenia. (...) Tak to konwenans zmuszał go [H Lipolita] do głębi do wyczerpania wraz z nami treści wyrazu „zabić”, ujrzal to, jak myśmy ujrzeli — jako okropność (P 130).

Bohaterowie - ludzie należący do „elity”, „dobrze wychowani” ${ }^{16}$ — zastanawiają się nac sposobem przeprowadzenia misji, nie dyskutują nad wyrokiem, bo on zostal im narzucony ale nad tym, kto ma przyjąć na siebie zło.

Zakwestionowane zostały podstawowe zasady gościnności, nie tylko chodzi tu o Witolda lecz - przede wszystkim - o Siemiana, który w gruncie rzeczy ma zostać zamordowany i zamordowany (wskutek działań gospodarza) zostaje. Świat wypadł ze swojego toru, ziemiańska rzeczywistość ulega destrukcji. To, co na początku narracji stanowiło jedynie prze. czucie zagrożenia, niepokój dotyczący możliwości powrotu do ziemiańskiej arkadii, okazuj się w miarę rozwoju opowieści coraz groźniejszym kwestionowaniem fundamentów zie. miańskiego bytowania. Wobec zla tkwiącego w ludziach rytuał okazuje się bezsilny, grzecz. ność zostaje unieważniona, gdyż rozpada się rzeczywistość wyznaczająca jej miejsce i funkcję

\footnotetext{
${ }^{16}$ Określenic to w powieści pochodzi - co znamicnnc - z wypowiedzi narratora: .,Więc nikt nikomu ni mógl pozwolić nawet na pozór stabości i gdyby $\mathrm{H}$ lipolit zaprowadzil nas od razu do Sicmiana, prawdopodob nie zalatwilibyśny to z rozpędu. Ale ta niespodzicwana komplikacja dawala nam pretekst do odlożenia dziala nia do następncj nocy. wszak trzeba bylo rozdziclić role, przygotować, zabezpieczyć... i stalo się jasne, że jeśl można odlożyć to trzeba odlożyć... więc mnic zlecono pilnowanie drzwi Siemiana do świtu, po czym mia muic zluzować Waclaw, i powiedzicliśmy sobie dobranoc, gdyż byliśny jednak osobani dobrze wychowany mi" (1'108).
} 
W tym właśnie znaczeniu Pornografia okazuje siç epopeją - rozkładu. Rytual nie jest w stanie powstrzymać "nowego" zla, które okazuje się niepodatne na dawne sposoby przeciwko niemu używane. Stopniowo posuwająca się erozja tradycji doszła do punktu, w którym rozkruszenie, rozsypanie się świata okazuje się nieuniknione i dokonuje się w sposób drastyczny - temat mlodości i erotyki w powieści (jombrowicza także sytunją się w tej perspektywie. Dopehniają więc obraz, który — jak autor powiada w Informacji (czyli przedmowie) jest trochę polski, „na wzór tanicgo romansu z gatunku Rodziewiczówny czy Zarzyckiej” (P 5), a trochę imaginacyjny, uniwersalny, albo — by posłużyć się formułą innego słymnego literackiego prowokatora: „rzecz dzieje się w Polsce, czyli nigdzie”.

Krótka konkluzja. Grzeczność u (rombrowicza, analizowana tu w jej tradycyjnej, sarmacko-szlacheckiej wersji, okazuje się istotnym skladnikiem dyskursu światopoglądowego budowanego w kolejnych powieściach odwołujących się do rzeczywistości dworkowo-ziemiańskiej. Bunt wobec niej, nieuniknioność uwikłania i destrukcja świata, który stanowił dla niej oparcie, uzasadniał ją, stanowią dominanty poszczególnych ujęć. Jednocześnie widoczne było w prowadzonym wywodzie — man nadzieję - funkcjonowanie rytualów grzeczności w Gombrowiczowskim myśleniu o formie, w ksztaltowaniu obrazu Innego, w rozumieniu napięć międzyludzkich. Grzeczność (i na ten aspekt starałem się polożyć najmocniejszy nacisk) okazuje się dla Gombrowicza terenem, na którym - również dzięki prowokacji można rozgrywać walkę z narodową tradycją: buntowniczo i buńczucznie, jak w Ferd)'durke, egzotycznie i emigracyjnie, groteskowo i nostalgicznie, jak w Trans-4tantykn - a wreszcie jak w Pornografii - opowiadając inną przygodę, jedną z najbardziej fatalnych. I zaiste, była ona fatalna, gdyż oznaczala koniec pewnego świata, pewnej epoki, pewnej tradycji i pewnej grzeczności, o których pod „nową władzą” pamiętali już tylko tzw. „bezeci”, czyli „byli ziemianie". 